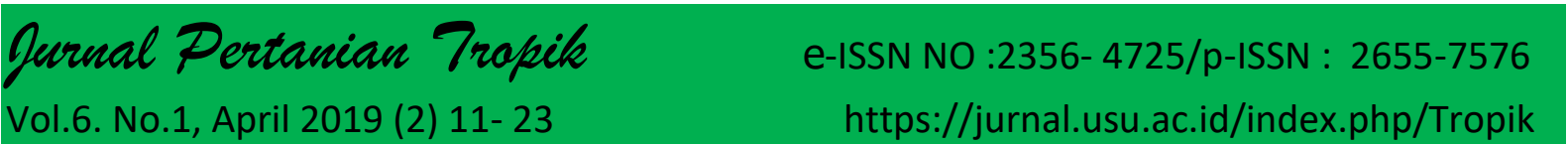

\title{
Keragaman Biologi Colletotrichum spp. Penyebab Penyakit Hawar Daun Pada Tanaman Kelapa Sawit (Elaeis guineensis Jacq.) Di Sumatera Utara Bagian Timur.
}

Biological Diversity of Colletotrichum spp. causes leaf blight disease in oil palm plants (Elaeis gueneensis Jacq.) in Eastern Northern Sumatera.

\section{Faisal Azhari, Hasanuddin*, Mukhtar Iskandar Pinem}

Program Studi Agroteknologi, Fakultas Pertanian USU Medan 20155

*Corresponding Author: hasanuddiny@yahoo.com

\begin{abstract}
The purpose of this research was to know the characteristics of Colletotrichum conidia isolated from oil palm in spread area of oil palm leaf blight disease in Labuhan Batu Selatan and Asahan. The research was conducted at Plant Disease Laboratory, Department of Agrotechnology, Faculty of Agriculture, University of Sumatera Utara from April 2017 until July 2017. Furthermore, Colletotrichum isolates were incubated using medium potato dexstrose agar (PDA) with 4 levels temperature $20^{\circ} \mathrm{C}, 25^{\circ} \mathrm{C}, 30^{\circ} \mathrm{C}$, and $35^{\circ} \mathrm{C}$ for 7 days light or dark. The research was conducted by survey method with length and width of conidia. The results showed the incubation at $35^{\circ} \mathrm{C}$ conidia from all isolates were smaller than at $20^{\circ} \mathrm{C}$, $25^{\circ} \mathrm{C}, 30^{\circ} \mathrm{C}$. The best temperature for Colletotrichum conidia from the $N L$ and DS at $30^{\circ} \mathrm{C}$ in light and dark, and $\mathrm{AJ}$ at $20^{\circ} \mathrm{C}$ in dark, in this condition the conidia becomes lenghty and increase width. At $35^{\circ} \mathrm{C}$ has reduced the fitness of conidia as an infectious organ of Colletotrichum.
\end{abstract}

Key word : Colletotrichum, Temperature, Conidia

\begin{abstract}
ABSTRAK
Tujuan penelitian ini adalah untuk mengetahui karakteristik konidia Colletotrichum yang diisolasi dari kelapa sawit di daerah penyebaran penyakit hawar daun kelapa sawit di Labuhan Batu Selatan dan Asahan. Penelitian dilakukan di Laboratorium Penyakit Tanaman, Program Studi Agroteknologi, Fakultas Pertanian, Universitas Sumatera Utara dari April 2017 hingga Juli 2017. Selanjutnya, isolat Colletotrichum diinkubasi menggunakan medium agar kentang dektrosa (PDA) dengan 4 tingkatan suhu $20^{\circ} \mathrm{C}, 25^{\circ} \mathrm{C}, 30^{\circ} \mathrm{C}$, dan $35^{\circ} \mathrm{C}$ selama 7 hari terang atau gelap. Penelitian dilakukan dengan metode survei dengan panjang dan lebar konidia. Hasil penelitian menunjukkan bahwa inkubasi pada $35^{\circ} \mathrm{C}$ conidia dari semua isolat lebih kecil dari pada $20^{\circ} \mathrm{C}, 25^{\circ} \mathrm{C}, 30^{\circ} \mathrm{C}$. Suhu terbaik untuk Colletotrichum conidia dari NL dan DS di $30^{\circ} \mathrm{C}$ dalam terang dan gelap dan $\mathrm{AJ}$ di $20^{\circ} \mathrm{C}$ dalam gelap, dalam kondisi ini konidia menjadi lenghty dan meningkatkan lebar. Pada suhu $35^{\circ} \mathrm{C}$ telah mengurangi kebugaran konidia sebagai organ infeksi Colletotrichum.
\end{abstract}

Kata Kunci : Colletotrichum, Suhu, Konidia

\section{PENDAHULUAN}

Kelapa sawit (Elaeis guineensis Jacq.) merupakan salah satu komoditi hasil perkebunan yang mempunyai peran cukup penting dalam kegiatan perekonomian di
Indonesia. Pasar potensial yang akan menyerap pemasaran minyak sawit (CPO) dan minyak inti sawit (PKO) adalah industri fraksinasi/rafinasi (terutama industri minyak goreng), lemak khusus (cocoa butter substitute), 
margarine/shortening, oleochemical, dan sabun mandi (BPS, 2014).

Secara nasional produk kelapa sawit menjadi sumber devisa terbesar kedua setelah minyak dan gas bumi. Sementara di pasar dunia, Indonesia saat ini bahkan sudah menjadi negara produsen dan pengekspor produk Kelapa Sawit yang terbesar. Lebih dari $40 \%$ kebutuhan minyak sawit dunia dipasok dari Indonesia. Selain sebagai bahan pangan, kebutuhan terhadap minyak sawit juga dipicu oleh penggunaannya sebagai sumber energi yang terbarukan, menggantikan bahan bakar fosil (Yunikartika, 2015).

Sampai tahun 2015 ini areal perluasan dan produksi perkebunan kelapa sawit terus mengalami peningkatan. Untuk luasan perkebunan di Indonesia mencapai 11.300.370 Ha dengan produksi 31.284.306 Ton, sementara di Sumatera Utara sendiri perkebunan sawit memiliki luas 1.186.866 Ha dengan produksi 5.099.246 Ton (Dirjenbun, 2016).

Namun dalam peningkatan produksi kelapa sawit sendiri memiliki beberapa kendala, termasuk penyakit hawar daun yang disebabkan oleh patogen Colletotrichum. Beberapa spesies Colletotrichum menyerang hampir semua tanaman tropis dan subtropis dan menyebabkan kerugian yang luar biasa dengan kebanyakan merusak buah, dengan mengurangi hasil melalui kerusakan bunga, atau dengan mempengaruhi daun, batang dan buah, sehingga mengurangi hasil kualitas yang dihasilkan dari buah, akar, dan lainnya (Agrios, 2004).

Diketahui beberapa spesies Colletotrichum menyerang tanaman pangan seperti kacang hijau (C. lindemuthianum), Kedelai (C. truncatum) (Semangun, 1993), tanaman buah seperti pepaya (C. gloeosporiedes) (Hafsoh, 2007), pisang (C. musae), mangga (C. gloeosporiedes) (Bruce Da Silva dan Michereff, 2013).
Diketahui pula Colletotrichum spp. juga menyerang tanaman kelapa sawit (Purnamasari, 2013).

Untuk mengetahui spesies Colletotrichum yang menyerang berbagai tanaman dapat dilakukan dengan melihat keragaman biologinya. Adaskaveg dan Hartin (1997) menyatakan respon terhadap suhu dapat digunakan untuk menunjukkan kesamaan antar isolat Colletotrichum. Penyataan ini juga didukung oleh Freeman et al. (1998) yang menyatakan bahwa identifikasi spesies Colletotrichum dapat dilakukan dengan melihat karakter morfologi seperti koloni dan warna biakan, ukuran dan bentuk konidia, suhu optimal dan tingkat pertumbuhan.

Penyakit hawar daun kelapa sawit yang disebabkan patogen Colletotrichum dapat menghasilkan serangan dengan kerusakan yang sangat parah hingga menjadi epidemi di daerah tertentu. Jika masuk ke suatu daerah baru, suatu penyakit dapat berkembang dengan cepat dan menjadi epidemi yang berat. Hal yang sama akan terjadi bila timbul ras atau strain patogen baru yang virulen. Bahkan adanya kultivar rentan yang ditanam secara luas dapat menyebabkan timbulnya epidemi. Epidemi terutama terjadi karena munculnya ras baru dari patogen lama, sedang tanaman tidak mempunyai gen ketahanan terhadap ras baru itu (Semangun, 1996).

Epidemi penyakit tanaman berkembang sebagai hasil dari kombinasi tepat waktu dari unsur - unsur yang sama yang mengakibatkan penyakit tanaman yakni : tanaman inang rentan, patogen virulen, dan kondisi lingkungan yang menguntungkan dan hal ini terjadi selama periode waktu yang relatif lama (Agrios, 2004). 


\section{BAHAN DAN METODE}

Penelitian ini dilaksanakan di Laboratorium Penyakit Tumbuhan dan Laboratorium Sentral Program Studi Agroteknologi, Fakultas Pertanian Universitas Sumatera Utara yang berada pada ketinggian tempat $\pm 25 \mathrm{~m}$ dpl dimulai pada bulan April 2017 sampai dengan Juli 2017.

Bahan yang digunakan dalam penelitian ini adalah sampel tanaman kelapa sawit yang terinfeksi Colletotrichum spp., media Potato Dexstrose Agar (PDA), alkohol 96\%, aquades, khlorox, cling warp, alumunium foil, label, tissue, spiritus, plastik, dan kapas.

Alat yang digunakan dalam penelitian ini adalah mikroskop compound, colour chart, inkubator merk Incucell 200, timbangan analitik, coke bore, petridish, erlenmeyer, beaker glass, bunsen, kamera, inkubator, preparat, kotak hitam, deglass, tabung reaksi, laminar air flow, mikropipet, baki plastik, spatula, dan jarum inokulum.

Metode penelitian yang digunakan dalam penelitian ini adalah metode survei. Adapun caranya adalah dengan mengamati secara langsung daun tanaman kelapa sawit yang terserang penyakit hawar daun tanpa melihat umur tanaman. Sampel daun diambil dari 3 lokasi yang berbeda yaitu Kebun Asian Agri di Negeri Lama (NL), Air Joman (AJ) di Kabupaten Asahan, Desa Sidorukun (DS) di Kabupaten Labuhan Batu.

\section{HASIL DAN PEMBAHASAN}

\begin{tabular}{l} 
Dari pengamatan warna \\
jamur Collototrichum \\
masing - masing daerah, didapatkan hasil \\
bahwa terdapat perbedaan warna pada \\
setiap isolat Colletotrichum dari ketiga \\
sampel daerah yang diujikan. \\
\multicolumn{2}{c}{ Warna koloni }
\end{tabular} Colletotrichum isolat NL yang telah diinokulasikan pada media PDA berwarna putih cerah pada awal pertumbuhannya kemudian berubah menjadi hitam pada media yang telah tua, seperti yang tersaji pada gambar 1a, 1b, dan 1c.

Warna koloni jamur Colletotrichum isolat DS yang telah diinokulasikan pada media PDA berwarna putih cerah pada awal pertumbuhannya kemudian berubah menjadi merah jambu pada media yang telah tua, seperti yang tersaji pada gambar 2a, 2b, dan 2c.

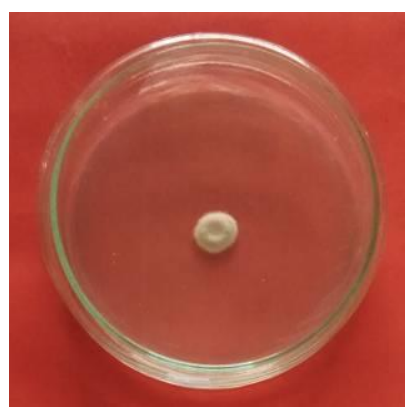

Gambar 1a. Biakan 2 hsi

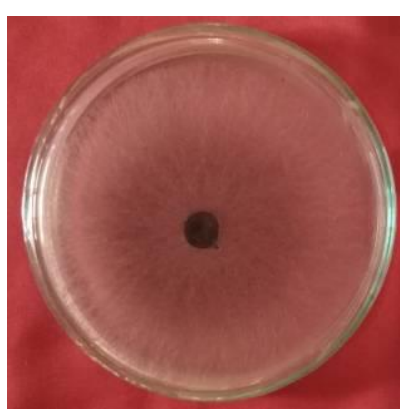

Gambar 1b. Biakan 5 hsi

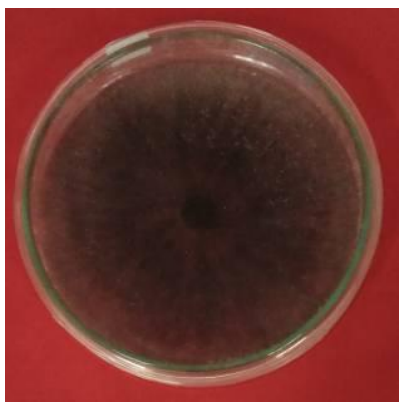

Gambar 1c. Biakan 7 hsi 


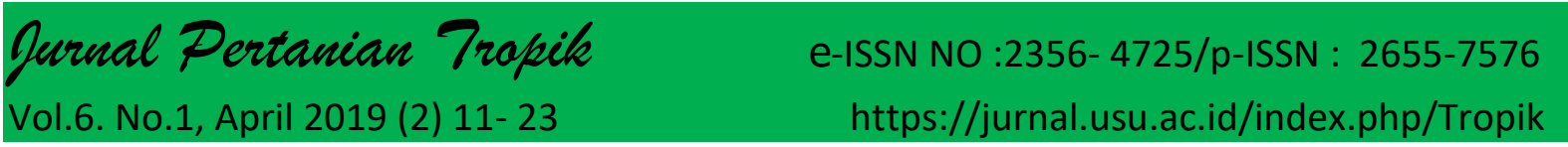

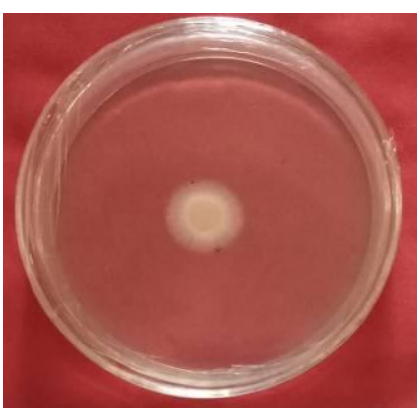

Gambar 2a. Biakan 2 hsi

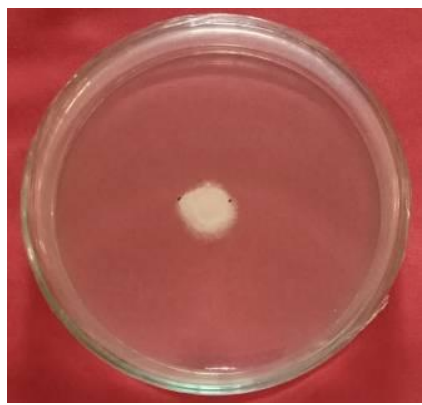

Gambar 3a. Biakan 2 hsi

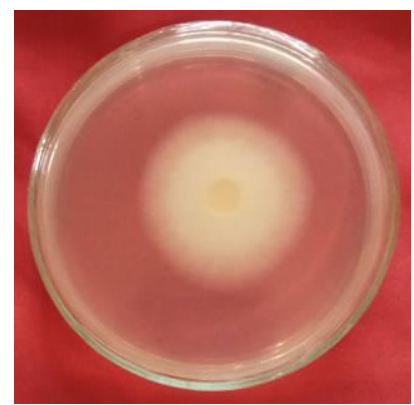

Gambar 2b. Biakan 5 hsi

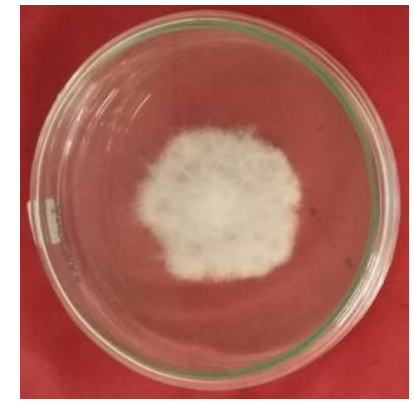

Gambar 3b. Biakan 5 hsi

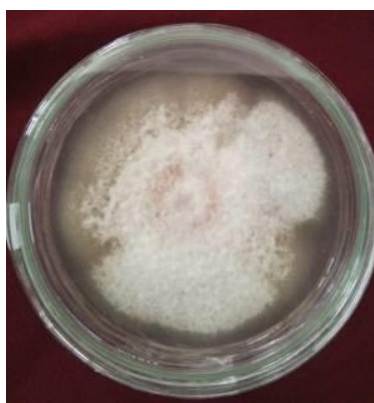

Gambar 2c. Biakan 7 hsi

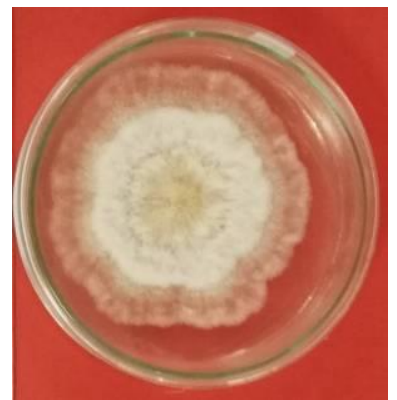

Gambar 3c. Biakan 7 hsi
Warna koloni jamur

Colletotrichum isolat AJ yang telah diinokulasikan pada media PDA berwarna putih cerah pada awal pertumbuhannya kemudian berubah menjadi kelabu pada media yang telah tua, seperti yang tersaji pada gambar $3 \mathrm{a}, 3 \mathrm{~b}$, dan $3 \mathrm{c}$.

\section{Pengamatan Miksoskopis Jamur Colletotrichum spp.}

Dari hasil pengamatan mikroskopis jamur Colletotrichum spp. pada masing - masing daerah, didapatkan hasil bahwasannya jamur Colletotrichum memiliki konidia jorong memanjang dan hifa bersekat. Hal ini sesuai dengan literatur Semangun (2000) yang menyatakan Colletotrichum umumnya mempunyai konidium hialin, bersel satu, berukuran 9-24 x 3-6 $\mu \mathrm{m}$, jorong memanjang, terbentuk pada ujung konidiofor yang sederhana.

Hasil pengamatan mikroskopis isolat NL dapat dilihat pada Gambar 7.

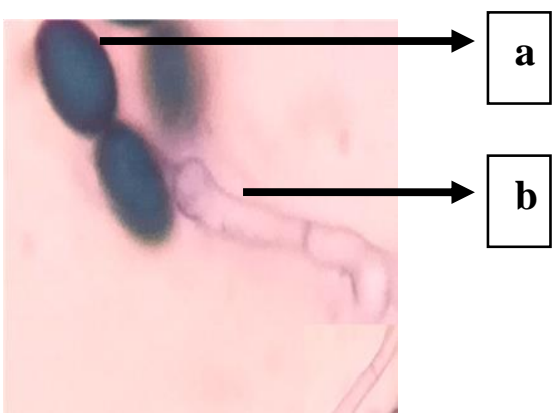

Gambar 4. a. Konidia b. Hifa Colletotrichum spp. 
Hasil pengamatan mikroskopis isolat DS dapat dilihat pada Gambar 8.

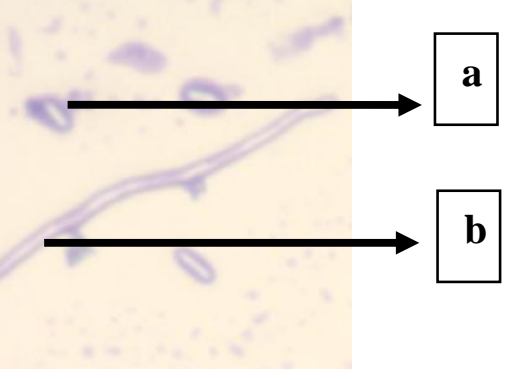

Gambar 5. a. Konidia b. Hifa Colletotrichum spp.

Hasil pengamatan mikroskopis isolat AJ dapat dilihat pada Gambar 9.

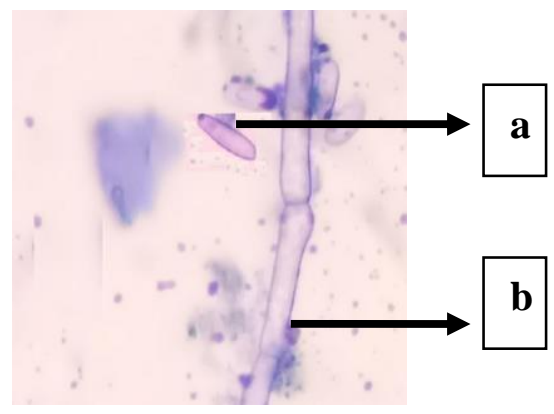

Gambar 6. a. Konidia b. Hifa Colletotrichum spp.

\section{Diameter Pertumbuhan}

Hasil penelitian menunjukkan keragaman diantara masing - masing isolat Colletotrichum yang telah di uji. Walaupun gejala serangan yang ditimbulkan pada setiap daun kelapa sawit memiliki kesamaan, namun setelah di ujikan dengan berbagai perlakuan suhu pada keadaan gelap dan terang menunjukkan keragaman biologinya. Hal ini dikarenakan terdapat keragaman (variabilitas) genetik dalam satu spesies patogen yaitu terdapat perbedaan ras - ras patogen, yang serangannya terbatas pada varietas tertentu dari satu spesies inang.
Perbedaan dalam biologi patogen Colletotrichum hingga mampu menyebabkan tingkat kerusakan yang tinggi bahkan mejadi epidemi di suatu daerah kemungkinan disebabkan oleh ras fisiologis dari patogen Colletotrichum itu sendiri. Hal ini dikarenakan dalam satu spesies patogen, terdapat ras - ras fisiologis patogen yang secara morfologis tidak dapat dibedakan, tetapi berbeda kemampuannya dalam menginfeksi kelompok - kelompok varietas inang yang berbeda. 


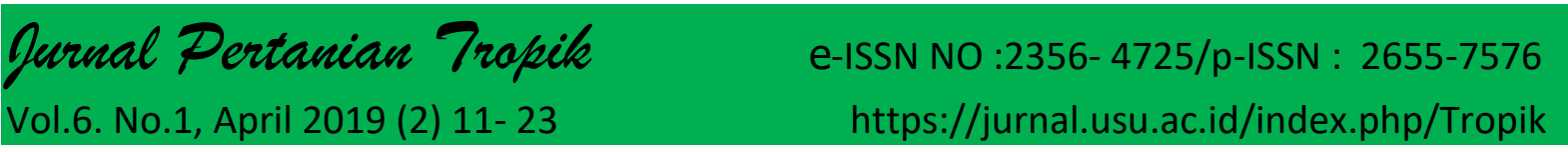

Tabel 1. Diameter Pertumbuhan Koloni Jamur Colletotrichum spp.

\begin{tabular}{|c|c|c|c|c|c|c|c|c|c|c|c|c|c|c|c|}
\hline \multirow{3}{*}{$\begin{array}{l}\text { Asal } \\
\text { Isolat }\end{array}$} & & \multicolumn{14}{|c|}{ Diameter Pertumbuhan Koloni $(\mathrm{cm})$} \\
\hline & \multirow[t]{2}{*}{ Suhu } & \multicolumn{2}{|c|}{$1 \mathrm{hsi}$} & \multicolumn{2}{|c|}{$2 \mathrm{hsi}$} & \multicolumn{2}{|c|}{$3 \mathrm{hsi}$} & \multicolumn{2}{|c|}{4 hsi } & \multicolumn{2}{|c|}{5 hsi } & \multicolumn{2}{|c|}{$6 \mathrm{hsi}$} & \multicolumn{2}{|c|}{$7 \mathrm{hsi}$} \\
\hline & & $\mathrm{G}$ & $\mathrm{T}$ & $\mathrm{G}$ & $\mathrm{T}$ & $\mathrm{G}$ & $\mathrm{T}$ & $\mathrm{G}$ & $\mathrm{T}$ & $\mathrm{G}$ & $\mathrm{T}$ & $\mathrm{G}$ & $\mathrm{T}$ & $\mathrm{G}$ & $\mathrm{T}$ \\
\hline $\mathrm{NL}$ & & 2,10 & 1,80 & 5,87 & 5,40 & 7,70 & 7,3 & 8,90 & 8,90 & - & - & - & - & - & - \\
\hline DS & $20^{\circ} \mathrm{C}$ & 0 & 0 & 0,53 & 0,66 & 1,36 & 1,18 & 2,05 & 1,85 & 2,51 & 2,29 & 3,15 & 3,08 & 3,67 & 3,85 \\
\hline $\mathrm{AJ}$ & & 0 & 0 & 0,17 & 0,17 & 0,48 & 0,40 & 0,77 & 0,65 & 0,94 & 0,93 & 1,13 & 1,20 & 1,35 & 1,63 \\
\hline $\mathrm{NL}$ & & 2,81 & 2,6 & 7,31 & 6,78 & 8,00 & 7,47 & 8,90 & 8,90 & - & - & - & - & - & - \\
\hline DS & $25^{0} \mathrm{C}$ & 0,27 & 0,3 & 0,88 & 0,99 & 1,41 & 1,77 & 2,54 & 2,91 & 3,45 & 4,20 & 4,08 & 5,15 & 4,57 & 5,97 \\
\hline AJ & & 0.10 & 0.21 & 0.61 & 1.18 & 0.98 & 1,70 & 1.65 & 2,66 & 2,30 & 3,63 & 2,61 & 4,38 & 2,92 & 5,43 \\
\hline NL & & 0,67 & 0,47 & 1,10 & 0,73 & 1,27 & 0,83 & 1,46 & 1,01 & 1,63 & 1,40 & 2,14 & 1,93 & 2,70 & 2,40 \\
\hline DS & $30^{\circ} \mathrm{C}$ & 0,67 & 0,63 & 2,00 & 1,60 & 3,07 & 2,93 & 4,00 & 3,87 & 5,17 & 5,13 & 5,87 & 5,67 & 7,07 & 6,40 \\
\hline AJ & & 0,93 & 0,87 & 2,07 & 1,90 & 3,00 & 2,70 & 3,87 & 3,67 & 5,13 & 4,97 & 5,87 & 5,53 & 6,6 & 6,27 \\
\hline $\mathrm{NL}$ & & 0,51 & 0,10 & 1,11 & 0,25 & 1,21 & 0,34 & 1,29 & 0,40 & 1,35 & 0,49 & 1,41 & 0,55 & 1,51 & 0,73 \\
\hline DS & $35^{\circ} \mathrm{C}$ & 0,21 & 0,18 & 0,55 & 0,48 & 0,77 & 0,71 & 1,03 & 0,85 & 1,23 & 0,99 & 1,47 & 1,11 & 1,71 & 1,33 \\
\hline $\mathrm{AJ}$ & & 0,11 & 0,15 & 0,31 & 0,21 & 0,45 & 0,31 & 0,53 & 0,47 & 0,63 & 0,57 & 0,69 & 0,68 & 0,88 & 0,80 \\
\hline
\end{tabular}

Keterangan : Batas pengukuran diameter dilakukan sampai 7 hari setelah inkubasi atau sampai miselium dari salah satu isolat telah memenuhi petri. NL : Negeri Lama; DS : Desa Sidorukun; AJ : Air Joman. G : Gelap; T : Terang.

Dari Tabel 1 dapat dilihat bahwasannya interaksi antara suhu, isolat dan masa inkubasi menunjukkan bahwa adanya perbedaan pertumbuhan miselium dari berbagai isolat Colletotrichum yang di ujikan. Hal ini dikarenakan penyakit yang disebabkan oleh patogen Colletotrichum spp. dapat berkembang dengan baik disebabkan oleh faktor lingkungan, seperti suhu. Setiap organisme dalam hal ini patogen Colletotrichum memiliki suhu optimum, dimana pada suhu optimum tersebut patogen akan tumbuh dengan baik.
Dari Tabel 1 juga dapat dilihat bahwasannya pengaruh cayaha pada kondisi gelap dan terang memberikan dampak untuk pertumbuhan miselium patogen Colletotrichum spp. yakni pertumbuhan terbaik miselium pada kondisi gelap. Hal ini sesuai dengan literatur Widyastuti dan Tjokrokusumo (2008) yang menyebutkan bahwa pertumbuhan miselium akan tumbuh dengan cepat dalam keadaan gelap atau tanpa sinar. 


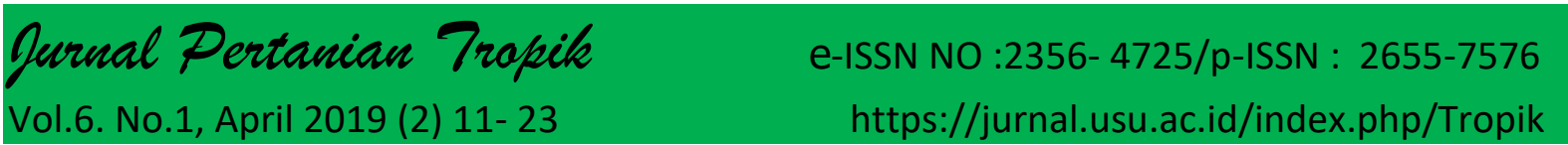

Tabel 2. Kecepatan dan Percepatan Pertumbuhan Koloni Jamur Colletotrichum spp.

\begin{tabular}{cccccc}
\hline \multirow{2}{*}{ Asal Isolat } & Suhu & \multicolumn{2}{c}{ Kecepatan Pertumbuhan (cm/hari) } & \multicolumn{2}{c}{ Percepatan Pertumbuhan (cm/hari) } \\
\cline { 3 - 6 } & & $\mathrm{G}$ & $\mathrm{T}$ & $\mathrm{G}$ & $\mathrm{T}$ \\
\hline $\mathrm{NL}$ & & 2,22 & 2,26 & 2,36 \\
$\mathrm{DS}$ & $20^{\circ} \mathrm{C}$ & 0,52 & 0,55 & 0,61 & 0,64 \\
$\mathrm{AJ}$ & & 0,19 & 0,37 & 0,22 & 0,27 \\
\hline $\mathrm{NL}$ & & 2,22 & 2,22 & 2,03 & 2,1 \\
$\mathrm{DS}$ & $25^{\circ} \mathrm{C}$ & 0,65 & 0,85 & 0,71 & 0,94 \\
$\mathrm{AJ}$ & & 0,41 & 0,77 & 0,47 & 0,87 \\
\hline NL & & 0,38 & 0,34 & 0,33 & 0,32 \\
DS & $30^{\circ} \mathrm{C}$ & 1,01 & 0,91 & 1,06 & 0,96 \\
AJ & & 0,94 & 0,89 & 0,94 & 0,90 \\
\hline NL & & 0,21 & 0,09 & 0,16 & 0,10 \\
DS & $35^{\circ} \mathrm{C}$ & 0,24 & 0,19 & 0,21 & 0,19 \\
AJ & & 0,12 & 0,11 & 0,12 & 0,10 \\
\hline
\end{tabular}

Keterangan : Perhitungan kecepatan dan percepatan pertumbuhan miselium isolat NL pada suhu $20^{\circ} \mathrm{C}$ dan $25^{\circ} \mathrm{C}$ dilakukan sampai 4 hsi karena telah memenuhi petri. NL : Negeri Lama; DS : Desa Sidorukun; AJ : Air Joman.G : Gelap; T : Terang.

Dari Tabel 2 dapat diamati bahwa pertumbuhan miselium dari isolat yang berbeda secara signifikan bervariasi dengan dipengaruhi oleh suhu, isolat dan masa inkubasi. Setelah diinkubasi selama 7 hari pada gelap dan terang, dari ketiga isolat menunjukkan pertumbuhan terbaik pada kisaran suhu $25^{\circ} \mathrm{C}-30^{\circ} \mathrm{C}$.

Dari Tabel 2 kecepatan pertumbuhan miselium yang lebih tinggi diamati pada suhu $20^{\circ} \mathrm{C}$ dan $25^{\circ} \mathrm{C}$ isolat NL $(2,22 \mathrm{~cm}$ dan $2,22 \mathrm{~cm})$ karna pada 4 hsi miselium sudah memenuhi petri, diikuti pada suhu $30^{\circ} \mathrm{C}$ isolat DS $(1,01 \mathrm{~cm}$ dan $0,91 \mathrm{~cm})$, dan pada suhu $30^{\circ} \mathrm{C}$ isolat AJ $(0,94 \mathrm{~cm}$ dan $0,89 \mathrm{~cm})$. Sedangkan pada suhu $35^{\circ} \mathrm{C}$, ketiga isolat menunjukkan respon penghambatan pertumbuhan dengan kecepatan $0,21 \mathrm{~cm}$ dan $0,09 \mathrm{~cm}$ pada isolat $\mathrm{NL}$, $0,24 \mathrm{~cm}$ dan $0,19 \mathrm{~cm}$ pada isolat DS, dan 0,12 dan $0,11 \mathrm{~cm}$ pada isolat AJ. Hal ini dikarenakan setiap mikroba mempunyai suhu minimum, suhu optimum, dan suhu maksimum untuk pertumbuhannya. Suhu minimum adalah suhu terendah tetapi mikroba masih dapat hidup, suhu optimal adalah suhu paling baik untuk pertumbuhan mikroba dan suhu maksimum adalah suhu tertinggi untuk kehidupan mikroba.

Dari Tabel 2 percepatan pertumbuhan miselium yang lebih tinggi diamati pada suhu $20^{\circ} \mathrm{C}$ dan isolat NL $(2,26 \mathrm{~cm}$ dan $2,36 \mathrm{~cm})$, diikuti pada suhu $30^{\circ} \mathrm{C}$ isolat DS $(0,71 \mathrm{~cm}$ dan $0,94 \mathrm{~cm})$, dan 


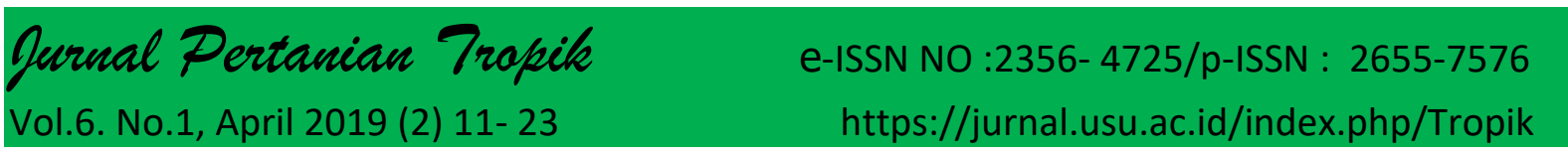

pada suhu $30^{\circ} \mathrm{C}$ isolat AJ $(0,94 \mathrm{~cm}$ dan $0,90 \mathrm{~cm})$. Sedangkan pada suhu $35^{\circ} \mathrm{C}$, ketiga isolat menunjukkan respon penghambatan pertumbuhan dengan kecepatan $0,16 \mathrm{~cm}$ dan $0,10 \mathrm{~cm}$ pada isolat NL, $0,21 \mathrm{~cm}$ dan $0,19 \mathrm{~cm}$ pada isolat DS, dan 0,12 dan $0,10 \mathrm{~cm}$ pada isolat AJ. Hal ini dikarenakan temperatur mempengaruhi aktivitas enzim dari cendawan. Pada temperatur rendah, reaksi enzimatis berlangsung lambat, kenaikan temperatur akan mempercepat reaksi, hingga suhu optimum tercapai dan reaksi enzimatis mencapai maksimum. Kenaikan temperatur melewati temperatur optimum akan menyebabkan enzim terdenaturasi dan menurunkan kecepatan reaksi enzimatis. Pandey et al. (2012) juga menyatakan bahwa suhu diatas $30^{\circ} \mathrm{C}$ menyebabkan efek hambat pada pertumbuhan Colletotrichum.

Patogen Colletotrichum spp. dapat terus berkembang karena dapat mempertahankan diri pada sisa - sisa tanaman sakit. Hal ini sesuai dengan literatur dari Semangun (1993) yang menyatakan bahwa karena konidium terikat dalam massa seperti lendir, pemencaran terutama disebabkan oleh air yang memercik. Colletotrichum spp. dapat mempertahankan diri pada sisa - sisa tanaman sakit. Jamur juga dapat terbawa oleh biji tanaman yang terbentuk didalam polong yang terinfeksi. CABI dan EPPO (1994) juga menyatakan dalam kondisi sesuai, jamur dapat tumbuh dengan cepat di dalam tanaman dan menyebabkan gejala parah dengan sangat cepat, namun dalam keadaan lain, jamur dapat tetap berada di dalam jaringan ingan dalam suatu periode, dan dalam beberapa kasus mulai nampak bergejala setelah panen.

\section{Pengukuran Konidia}

Dari pengamatan yang telah dilakukan, didapatkan hasil bahwa suhu terbaik untuk konidia Colletotrichum asal isolat $\mathrm{NL}$ dan $\mathrm{DS}$ adalah $30^{\circ} \mathrm{C}$ pada terang dan gelap, dan isolat $\mathrm{AJ}$ pada suhu $20^{\circ} \mathrm{C}$ pada gelap, pada kondisi ini konidia menjadi lebih panjang dan bertambah lebar, sedangkan suhu $35^{\circ} \mathrm{C}$ sudah mengurangi kebugaran konidia sebagai organ infeksius dari Colletotrichum. Penurunan kebugaran konidia sebagai organ infeksius yang terjadi pada suhu $35^{\circ} \mathrm{C}$ diakibatkan pada suhu tersebut ketersediaan air berkurang. Air sendiri berfungsi sebagai aktifator agar enzim enzim suatu mikroba sehingga reaksi metabolisme dapat bekerja dengan baik.

Ukuran konidia juga akan mempengaruhi viabilitas dari suatu patogen. Jika ukuran konidia mendekati normal sesuai spesies dari suatu patogen, maka daya kecambah serta daya infeksius dari konidia tersebut akan optimal. Karena pada saat konidia membentuk tabung kecambah dan melakukan penetrasi ke jaringan tanaman pastinya membutuhkan energi yang dihasilkan melalui proses metabolisme. Apabila ukuran konidia abnormal, maka proses metabolisme akan terganggu.

Dari Tabel 3 dapat diamati bahwa karakteristik konidia dari isolat yang berbeda bervariasi dengan dipengaruhi oleh suhu, isolat, dan cahaya. Setelah diinkubasi selama 7 hari gelap dan terang dengan suhu yang berbeda, ketiga isolat menunjukkan karakterisasi konidia yang beragam.

Pada suhu inkubasi $20^{\circ} \mathrm{C}$ diamati bahwa konidia isolat NL memiliki ukuran lebih besar baik diinkubasi pada terang dan gelap. Konidia isolat DS memiliki ukuran terkecil dibandingkan dengan konidia isolat NL dan AJ. Sedangkan konidia isolat $\mathrm{AJ}$ memiliki ukuran lebih panjang dan kecil dibandingkan isolat NL dengan perbandingan panjang dan lebar > 4. Perbandingan panjang dan lebar isolat NL dan DS yakni > 2 .

Pada suhu inkubasi $25^{\circ} \mathrm{C}$ diamati bahwa konidia dari isolat NL, isolat DS dan isolat AJ memiliki ukuran konidia 
yang tidak jauh berbeda dengan ukuran konidia yang diinkubasi pada suhu $20^{\circ} \mathrm{C}$.

Pada suhu inkubasi $30^{\circ} \mathrm{C}$ diamati bahwa konidia isolat DS pada kondisi terang dan gelap memiliki ukuran konidia yang lebih panjang dibandingkan ukuran konidia yang diinkubasikan pada suhu $20^{\circ} \mathrm{C}$ dan $25^{\circ} \mathrm{C}$, namun konidia isolat NL pada kondisi terang memiliki ukuran konidia yang lebih besar dibandingkan ukuran konidia yang diinkubasikan pada suhu $20^{\circ} \mathrm{C}$ dan $25^{\circ} \mathrm{C}$, sedangkan konidia isolat AJ ukurannya mengecil menjadi > 2 pada kondisi terang.

Pada suhu inkubasi $35^{\circ} \mathrm{C}$ diamati bahwa keadaan konidia pada isolat NL, isolat DS dan isolat AJ menjadi lebih kecil dibandingkan dengan diinkubasi pada suhu $20^{\circ} \mathrm{C}, 25^{\circ} \mathrm{C}$, dan $30^{\circ} \mathrm{C}$.

Pada Tabel 4 dapat dilihat bahwasannya terdapat keragaman cendawan patogen Colletotrichum spp. dari asal isolat yang berbeda. Keragaman ditunjukkan dengan perbedaan karakter dari masing - masing konidia asal isolat yang berbeda. Diketahui bahwa karakter konidia isolat NL adalah Ellipsoid, sedangkan karakter untuk isolat asal DS dan AJ adalah Naviculate. Hal ini sesuai dengan literatur dari Agrios (1996) yang menyatakan terdapat keragaman (varibialitas) genetik dalam satu spesies patogen yaitu terdapat perbedaan ras - ras patogen, yang serangannya terbatas pada varietas tertentu dari satu spesies inang.

Penentuan karakter konidia Colletotrichum spp. dari masing - masing isolat dilakukan dengan melihat perbandingan antara rasio $a: b$. Dimana pada saat a1 $=\mathrm{a} 2$, dapat dilihat bahwa pada kondisi tersebut konidia Colletotrichum memiliki kedudukan lebar yang tertinggi.

Keragaman karakter dari cendawan patogen Colletotrichum spp. dapat diketahui dengan mengukur konidianya. Hal ini sesuai dengan literatur dari Watanabe (2002) yang menyatakan bahwa keragaman biologi Colletotrichum spp. dapat dilihat secara mikroskopis dengan mengukur konidianya.

Kemampuan masing - masing isolat Colletotrichum untuk dapat tumbuh pada beberapa tingkatan suhu berbeda disebabkan karena Colletotrichum dari setiap isolat belum beradaptasi. Suhu yang sesuai untuk pertumbuhan patogen Colletotrichum adalah $25-28^{0} \mathrm{C}$. Hal ini sesuai dengan literatur Bruce Da Silva (2013) yang menyatakan spora tumbuh paling baik pada suhu $25-28^{\circ} \mathrm{C}$. 
Durnal Pertanian Tropile

Vol.6. No.1, April 2019 (2) 11- 23
e-ISSN NO :2356- 4725/p-ISSN : 2655-7576 https://jurnal.usu.ac.id/index.php/Tropik

Tabel 3. Karakteristik Konidia Colletotrichum spp. (Panjang, Lebar, Perbandingan Panjang dan Lebar)

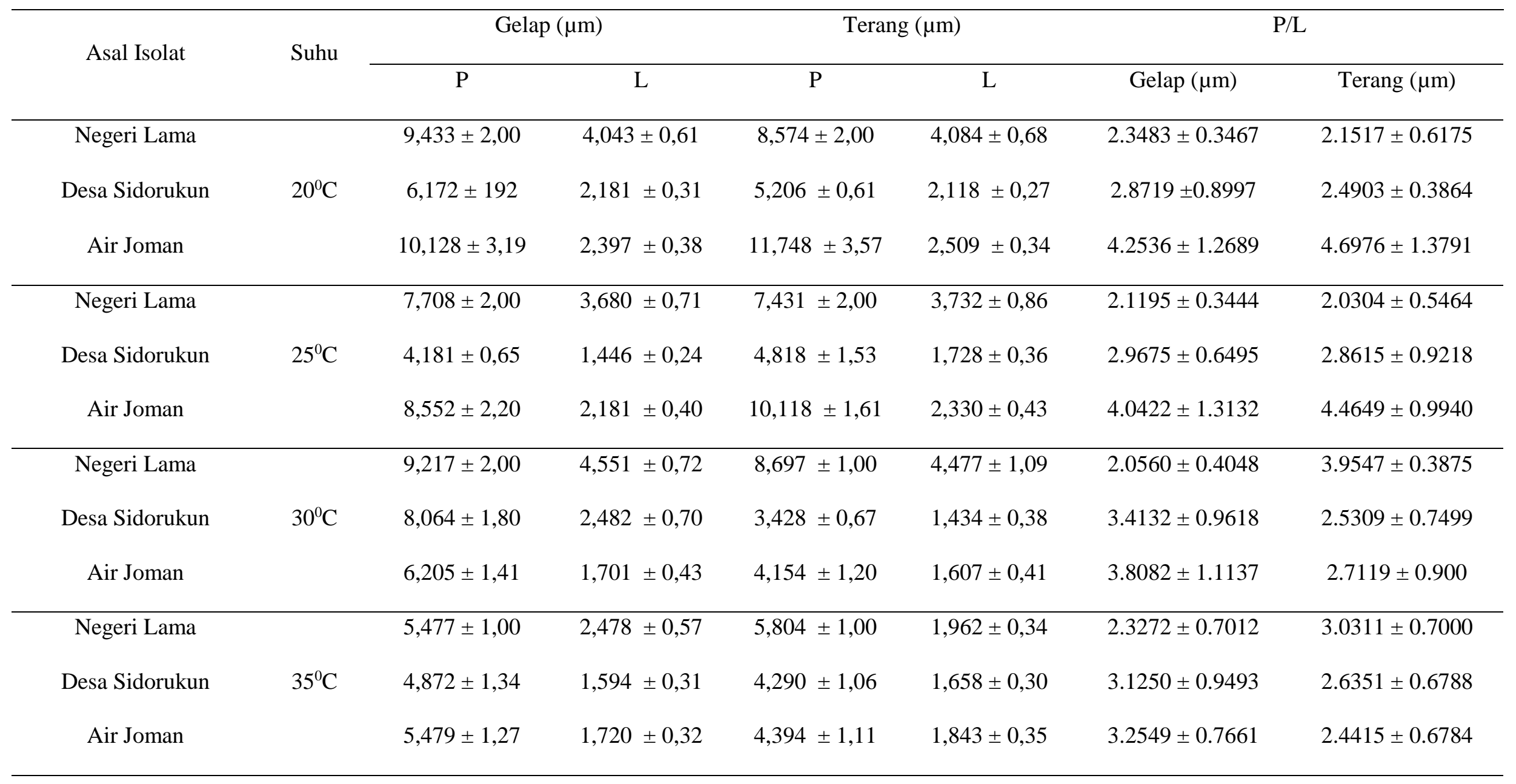


Tabel 4. Bentuk dimensi konidia Colletotrichum spp.

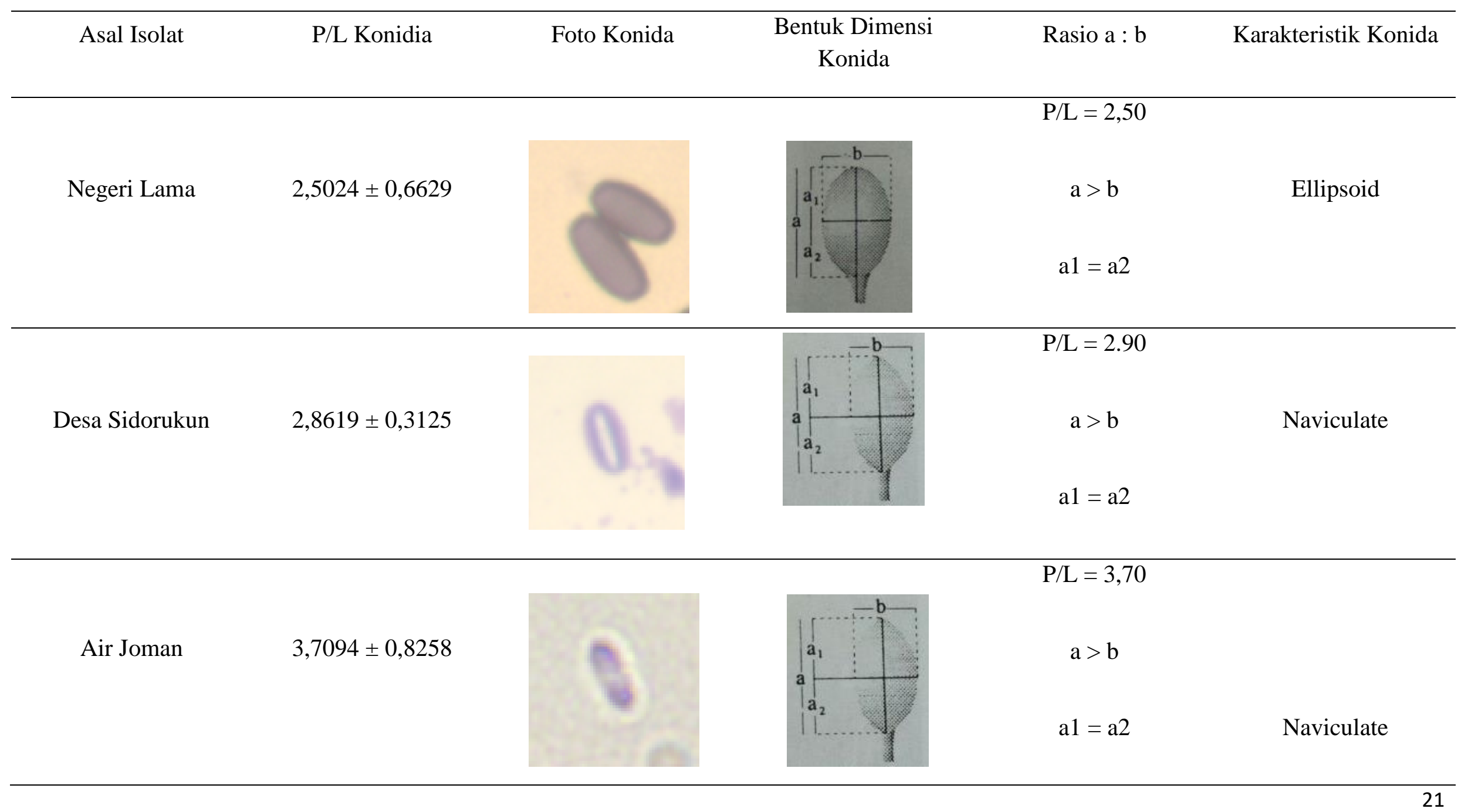




\section{SIMPULAN}

Terdapat keragaman biologi Colletotrichum penyebab penyakit hawar daun tanaman kelapa sawit pada masing - masing daerah sampel yang telah di ujikan. Keragaman ditunjukkan oleh perbedaan warna koloni, serta ukuran dan bentuk karakteristik konidia. Dari ketiga isolat Colletotrichum menunjukkan pertumbuhan miselium terbaik pada kisaran suhu $25^{\circ} \mathrm{C}-30^{\circ} \mathrm{C}$. Suhu $35^{\circ} \mathrm{C}$ menyebabkan konidia Colletotrichum dari ketiga isolat mengalami pengurangan kebugarannya sebagai organ infeksius.

\section{DAFTAR PUSTAKA}

[BPS] Badan Pusat Statistik. 2014. Statistik Kelapa Sawit Indonesia 2014. http://www.bps.go.id [diakses tanggal 24 Januari 2017].

[Dirjenbun] Direktorat Jenderal Perkebunan. 2016. Statistik Perkebunan Indonesia 2014 2016. Jakarta.

Adaskaveg. J.E. dan Hartin, R.J.. 1997. Characterization of Colletotrichum acutatum Isolates Causing Antrachnose of Almond and Peach in California. Departmen of Plant Pathology. University of California. Riverside.

Agrios, G.N. 1996. Ilmu Penyakit Tumbuhan. Diterjemahkan oleh Busnia M. UGM Press. Yogyakarta. Hal 8,18.

Agrios, G.N. 2004. Plant Pathology. $5^{\text {th }}$ Edition. Elsevier Academic Press. London.

Bruce Da Silva, C.D.E dan Michereff, S.M. 2013. Biology of Colletotrichum spp. and Epidemiology of the
Antracnose in Tropical Fruit Trees. Universidade Federal Rural do Semi-Árido.

CABI dan EPPO. 1994. Data sheets on Quarantine Pests : Colletotrichum acutatum. EU Annex designation: II/A2. Under Contract 90/399003.

Freeman, S., T. Katan., dan E. Shabi. 1998. Characterization of Colletotrichum Species Respnsible For Anthracnose Diseases of Various Fruits. The Volcani Center. Bet Dragan. Israel. Plant Disease. Vol. 82 No. 6

Hafsoh, S. 2007. Studi Patogen Penyebab Antraknosa Pada Pepaya. Program Studi Agronomi Sekolah Pascasarjana. Institut Pertanian Bogor. Bogor.

Pandey, A., L.P. Yadava., M. Manoharan., U.K. Chauhan dan B.K. Pandey. 2012. Effectiveness of Cultural Parameters on the Growth Sporulation of Colletotrichum gloeosporoides Causing Antracnose Disease of Mango (Mangifera indica L.). Online Journal of Biological Sciences, 2012, 12 (4), 123 - 133. ISSN : 1608 4217.

Purnamasari, D. 2013. Isolasi dan Seleksi Bakteri Selulotik Penghambat Pertumbuhan Cendawan Pada Tanaman Kelapa Sawit. Departemen Biologi. Fakultas Matematika dan Ilmu Pengetahuan Alam. Institut Pertanian Bogor. Bogor.

Semangun, H. 1993. Penyakit - Penyakit Tanaman Pangan di Indonesia. Gadjah Mada University Press. Yogyakarta. 
Semangun, H. 1996. Pengantar Ilmu Penyakit Tumbuhan. Gadjah Mada University Press. Yogyakarta. Hal: 98 - 103.

Semangun, H. 2000. Penyakit - Penyakit Tanaman Perkebunan di Indonesia. UGM Press. Yogyakarta. Hal : 395 - 399.

Watanabe, T. 2002. Pictorial Atlas of Soil and Seed Fungi : Morphologies of Cultural Fungi and Key to Species. Second Edition. CRC Press. London
Widyastuti, N. dan Tjokrokusumo, D. 2008. Aspek Lingkungan Sebagai Faktor Penentu Keberhasilan Budidaya Jamur Tiram (Pleurotus sp). Badan Pengkajian dan Penerapan Teknologi. J. Tek. Ling Vol. 9 No. 3. Hal. 287 $-293$.

Yunikartika, R. 2015. Ekspansi Kelapa Sawit di Pulau Kalimantan. INTIPHUTAN-FOREST WACH INDONESIA. 